\title{
Transcultural Psychiatry and the French Provision of Health for Migrants: Between Mediation and Misunderstanding
}

Dafne Accoroni

\section{(2) OpenEdition \\ Journals}

Electronic version

URL: http://journals.openedition.org/transtexts/991

DOI: 10.4000/transtexts.991

ISSN: 2105-2549

Publisher

Gregory B. Lee

Electronic reference

Dafne Accoroni, «Transcultural Psychiatry and the French Provision of Health for Migrants: Between Mediation and Misunderstanding », Transtext(e)s Transcultures 跨文本跨文化 [Online], 12 | 2017, Online since 25 October 2018, connection on 01 May 2019. URL : http://journals.openedition.org/ transtexts/991; DOI : 10.4000/transtexts.991

This text was automatically generated on 1 May 2019.

(c) Tous droits réservés 


\title{
Transcultural Psychiatry and the French Provision of Health for Migrants: Between Mediation and Misunderstanding
}

\author{
Dafne Accoroni
}

\section{Methodology}

1 I carried out multi-sited ethnographic fieldwork at two different sites in Paris: in a foyer ${ }^{1}$ of the île-de-France region and at the transcultural psychiatric Bellevue Centre for migrants' mental health. ${ }^{2}$ I spent a year long period at the former, where I conducted participant observation, semi-structured and focus group interviews. The foyer, in the in the departmental area of Seine-Saint-Denis, is commonly referred to as the 'neuf-trois', the 'nine-three', in reference to its postal code, 93. According to the 2013 census, the neuftrois has the highest number of migrants of the whole Île-de-France region (predominantly of Western and Northern African origin) and also has the highest mortality and unemployment rates compared to the national figures (respectively 5.7 per thousand and $13.5 \%$ ). ${ }^{3}$ The residents of the foyer ${ }^{4}$ provide the case study for the firstgeneration migrants' health seeking behaviour and coping strategies.

2 I spent the first six months of my ethnographic data collection at the Bellevue Centre. The Centre delivers transcultural psychiatry to migrant patients with the support of a multi-disciplinary team made up of psychiatrists, psychologists, social workers and anthropologists from Anglophone countries (Canada and the United Kingdom). As a medical anthropologist, I contributed to the research and study groups run by the Centre and participated in the team's weekly meetings. Here, I could observe the provision of mental health services for migrants, and the latter's attendance and composition. 


\section{Background: Transcultural Psychiatry in France}

3 The aftermath of World War Two brought with it a huge movement of people from the ex-colonies (due to the need for a labour force in the reconstruction of France, to care for and assist orphans, refugees and so forth), so that interest in mental health studies began to shift towards comparative approaches with respect to people from different social and cultural backgrounds. ${ }^{5}$ At this time, the World Federation for Mental Health was created by 'J.R. Rees, the chief of the psychiatric services of the British army'; there followed by H.B.M. Murphy's comparative studies on 'dispersed people' (in particular refugees) that also revealed the impact of migration on the aetiology of psychopathologies. ${ }^{6}$ Hence, interest shifted toward the evaluation of cultural difference as a focal element in psychoanalysis and therapy. In 1957, the American Association of Anthropology dedicated its annual meeting to the theme of 'Culture and Mental Health', while the newly formed World Psychiatric Association organised a conference on the same theme. ${ }^{7}$

Comparative and transcultural psychiatry became the arena for the confrontation of analyses reading colonization and the colonised people in psychological (cf. Mannoni) and socio-political terms, while historical, political conjunctures and cultural representations became ways of addressing psychopathology. ${ }^{8}$ In France, scientific attention focussed on the colonies in West and North Africa as a way of solving the 'African problem'. ${ }^{9}$ Anthropological work moved towards the knowledge and description of local understandings of illness and suffering, thus producing a shift towards 'cognitive and semantic anthropology'. ${ }^{10}$ In Senegal, the Ortigues and Zempleni attempted to make sense of the culturally-framed meaning and expression of psychopathology, so challenging their supposed universality that often coincided with ethnocentric views, while psychiatrist Collomb at the Fann Hospital of Dakar carried out unprecedented community-based therapy. ${ }^{11}$ Collomb implemented classical psychiatric care within a network in which both the hospital and the community provided support to the patient; this would become one of the ground-breaking tools of this new transcultural epoch. This project was never replicated in Paris, although, among grassroots associations working on migration and health, healers are currently invited to discuss and reflect on the possibility of bridging the gap between the biomedical system and the 'traditional' one.

In France, 'ethnopsychiatry reached its apogee with the foundation of the George Devereux Centre, annexed to the University of Paris VIII (1993).$^{12}$ Devereux ${ }^{13}$ inaugurated a new way of doing psychiatry, by combining clinical practice, research and teaching. Tobie Nathan, his student, championed his teacher's approach by associating anthropology and psychiatry as ethnopsychiatry. ${ }^{14}$ From his perspective, to have a migrant in therapy in France would imply reproducing the migrant's milieu in the therapeutic setting by introducing, for example, amulets (or other objects) and the group (made up of a number of therapists and experts on the patient's culture). Both the use of objects and of the group were consistent, in Nathan's clinical practice, with the migrant's traditional environment. Nonetheless, Nathan's theory and clinical practice have been subjected to criticism in recent years by both anthropologists and clinicians in France, who accuse him of carrying out 'folk therapy' and reducing the migrant to a mere copy of his supposed culture of origin. First among the critics is anthropologist Didier Fassin addressing in particular healthcare among Western African migrants. ${ }^{15}$ Implicit in both his critique and in the clinical work currently carried out in Paris is the refusal to think of 
the migrant's adaptation as a one way-process. The patient's wellbeing is thus simply not achieved once the migrant has re-integrated himself into his own community (from which he has probably distanced himself, voluntarily or not). Fassin clearly attacks Nathan in his 1999 article, whose title paraphrases Nathan's famous book L'influence qui guérit, expanding on the theory of one's origin as the main formative experience of one's psyche. Such a datum, according to Nathan, would be incontrovertible. ${ }^{16}$ Fassin, by referring to Foucault, shows how colonialism constituted a 'war of races, construed as a tension between a nostalgic ideal of sovereignty and a one made up of bio-politics', in which again and again, the supremacy of one people over another is condoned. ${ }^{17}$ In Fassin's analysis, echoing British transcultural psychiatry, what is at stake in the migrants' healthcare, is precisely the affirmation of power (of the dominant group) over those excluded from it (the migrants and the subdominant groups). ${ }^{18}$ This may occur in various guises, he says, from blatant racism to obtuse reductionism in therapy, making of one's culture one's exclusive fate, or rather, one's 'culture as a closed, undivided reality, impossible to share, the reason why cultures have to be differentiated (...) by watertight frontiers' and thus dominated. ${ }^{19}$ Moreover, the author argues that migration and health have long occupied a marginal space within the study of tropical diseases, a subcategory relegating the migrants, with their culture and/or diseases, to a minor field of interest. ${ }^{20}$ Culturalism, another concept at the heart of current criticism and research in France, marked the migrants as people exhibiting certain cultural and biological characteristics, which were 'other' or 'different' from those borne by the larger community. Fassin cites paludisme (malaria), saturnism (lead poisoning) and so forth, as examples of migrants' illnesses, to which healthcare services responded with tailored programmes of prevention and information.

6 Littlewood and Lipsedge question whether specific migrant illnesses exist, or to put differently, whether there might be a 'migrant's psychopathology', due to the difficulty engendered by his/her adaptation process. ${ }^{21}$ In this sense, grassroots, clinical and anthropological work shows that the answer is a mixed one, in that illness is a complex experience entailing both societal (of the sending and receiving countries) and individual meaning-making beyond the specificity of the physical disease. In Europe, and in France in particular, healthcare for minority groups has been associated over time with social rights and, more specifically, with the right to receive healthcare, regardless of one's status (legal or illegal migrant). Fassin subtly remarks that in France there has been another shift: from the successful fight to obtain human rights such as healthcare for all, to the demand for social rights on the grounds of medical need. Thus, migrants may now claim residency rights, if they can prove that they can only receive treatment in France, so that social, political and anthropological debates have moved closer to the universalism of the droit commun, in the opposite direction to the initial struggles, advocating the recognition of migrants' rights and cultural difference. One again, Fassin's argument that migrants' mental health issues may, in fact, be political and economic in origin foregrounds how Nathan's cultural enclave and ritual objects approach neglect this possibility entirely.

7 There are now two main theoretical standpoints in French clinical theory. The first is acculturation, conceived of as a process of change in which the migrant becomes involved in the host community. The second is that of métissage (cultural and ethnic mixing), as the way of approaching the migrant population with an open gaze, which does not reduce the individual to his own background, but uses it instead as a valid tool of interpretation 
enabling an understanding of the ways in which pain and suffering are articulated socially, culturally and religiously. Psychiatrist Marie Rose Moro, a well-known figure on the transcultural psychiatric scene, has introduced the working concept of métissage in her practice with children born to migrant parents or to parents of migrant descent. She was Nathan's student and has incorporated part of her former mentor's teaching into her practice, while also distancing herself from some of its aspects; for example, she does not use ritual objects during psychotherapy. According to her, ethnographies of illness are essentially a methodological tool in transcultural psychiatry. ${ }^{22}$ Métissage is the element affirming the universality of the psyche, while maintaining cultural difference in its dynamism within the context and power relationships those children inhabit. ${ }^{23}$ This approach does not imprison the psyche in the determinism of one's background, but rather widens it towards the possibility of different choices, and thereby, towards an act of consciousness.

\section{Context}

\section{Foyer 93}

The foyers are a central issue for the Republic historically, politically and socially. The first ones emerged as a consequence of the France's post-war reconstruction, and its need for a labour force in the aftermath of World War II. The first residents were Algerians, hosted in foyers/dormitories, which were generally converted ex-factories. At the time, these buildings resembled military areas under the control of a guardian who watched over them permanently. The foyers now have a completely different status: the migrants living there are residents with whom neither the mayor of Paris nor the police nor other third parties can interfere unless criminal activities take place. Given the number of illegal migrants in the foyers, one wonders in fact, how this can be. Thanks to the infamous rebellions of the 1970s and the ongoing work of social services and associations in the foyers, the latter have reached the status of a social residence, or parc social, granting their residents the right to privacy. ${ }^{24}$ Nevertheless, the foyers are still no-go areas for French people. Those in Paris are particularly unsightly, being the oldest and never having been restored: many are falling apart and security and health are never guaranteed. Open sewage, no anti-fire measures, no hygiene in the collective kitchen and so on, demonstrate the way in which West African migrants' fate in France is entangled with the political and historical context which socially constructs their reality.

The foyers appear to be much like independent microcosms. They are spread out over the whole Île-de-France region and have been a part of the physical landscape for some time. Nonetheless, they remain foreign to most of the French people who are not directly involved with them. The "nine-three" foyer is located in Seine-Saint-Denis, to the North East of Paris, and is one of the banlieue closest to Paris, together with Haute de Seine and Val de Marne. ${ }^{25}$

Overall, Sub-Saharan migration represents only $12 \%$ of inward migration to France. Approximately thirty-seven thousand Malian migrants live legally in France, while another thousand are undocumented migrants, principally in the Paris region. ${ }^{26} \mathrm{My}$ work addresses the portion of male migrants who live in the foyers, about 150.000 men housed in 700 foyers, of which 250 are in the Île-de-France region (about 55.000 official places). ${ }^{27}$ As Timera has pointed out, notwithstanding the small number of people living there in 
comparison to the wider migrant population, the foyers are the gateway to future housing and work for West African migrants, especially when they are illegal. ${ }^{28}$ Thus, the foyers are representative of these migrants' strategies in settling in the big city, since over time they host different generations of migrants. This is also true for other groups from the Sahel, organised in the foyers by village of origin - not necessarily ethnically -, in Paris as much as in other cities of France such as Lyon and Marseille.

\section{The Bellevue Centre}

11 The Bellevue Centre was founded about forty years ago and has about two thousand patients currently in therapy (of whom $10 \%$ are children), corresponding to twelve thousand medical and non-medical sessions held each year. The Centre falls under the Agence Régionale de l'Hospitalisation d'Île-de-France, which means that the institute is under the control of the regional council as to preventive programmes and the promotion of mental health. This institute recruits its patients from the whole Île-deFrance region and its status is that of private health care institute (Établissement de Santé Privé d'Intérêt Collectif). The Bellevue Centre applies transcultural psychiatry in its practice with migrant patients. Medical anthropology, that is, the understanding of the migrants' cultural background in the aetiology, formation and expression of the illness is emphasised, analysed and managed by the team. Traditional healing is not part of the psychiatric care offered; as a method it is, in fact, criticized. However, traditional, religious, biographical and social elements, which may be conducive to the individual's formulation of the illness, are taken into account in order to provide a service which might best answer the migrants' needs and therapeutic demands.

The clinical unit premises its work on the notions of emic/etic, disease/illness as they were developed by Eisenberg and on the explanatory model as elaborated by American anthropologist and psychiatrist Kleinman on the relationship between illness and culture, wherein physical and psychic suffering are expressed according to cultural metaphors, a form of cultural dressing-up (habillage in French) specific to culture.$^{29} \mathrm{After}$ Kleinman, BC's working concepts are those of sickness, disease and illness, imbricated with a particular emphasis on the acculturation process of the migrant patient. Psychiatrists and psychologists attempt not simply to decode, but also to make sense of the patients' explanatory models of suffering, which may not correspond to the clinical and western nosography or even to the patient's actual behaviour. ${ }^{30}$ The ambivalence of the patients, split between two worlds is similar to that of the psychiatrist, also caught at the edge of two worlds: the French one, from which his therapeutic tradition stems, and that of the patients', which he is demanded to ameliorate.

The Bellevue Centre is the first medical institute to have inaugurated clinical medical anthropology in France. This entails meeting the migrants' demands in the clinical practice on the one hand, and on the other, training personnel in transcultural psychiatry by involving them in ongoing research. Hurdles that the team has to confront daily are language barriers and the difference in cultural representations between care-giver and patient, who might not share the 'implicit codes of the discourse about mental illness'. ${ }^{31}$ The Bellevue Centre has recently adopted the working concept of 'cultural competence', in accordance with other transcultural and international psychiatric milieus in the United States and the United Kingdom. 

neuroses (28\%), and schizophrenia (8\%), the remainder consisting of non-specified cases, drop-outs and so on. These diagnoses testify to the fact that an 'ontological implication between migration and illness cannot be drawn, but rather, that mood disorders appear within difficult migratory trajectories or devastating experiences of exile'. ${ }^{32}$

\section{Samba}

Samba has been one of the Bellevue Centre's users for a limited period. He is from Dakar Senegal, and aged forty-two. His clinical record reported him in a state of confusion and anxiety, while experiencing social marginality and achieving little progress in therapy. Samba had had a car accident in Paris, after which he could no longer cope with the normal course of life. When I met him, he had no employment apart from running a little jewellery workshop that provided him with the little revenue on which he lived. However, his social life was not so limited. He paid visits to a friend at Foyer93, generally on Fridays for the ritual prayer, and also frequented the Mouride Centre at Aulnay, in the Île-de-France region. ${ }^{33} \mathrm{He}$ had friends living in his neighbourhood, who paid him visits, and vice-versa, and he taught the Koran to the children where he lived. When we met, he was on medication. Samba shared a very modest flat to the north of Paris with a Senegalese friend. He had been referred to the Bellevue Centre by the mental health centre of Seine-Saint Denis. He had his carte vitale, or French social security card, that allowed him to have access to a doctor and free medication. ${ }^{34} \mathrm{He}$ did not attend the Bellevue Centre for long, and soon stopped going altogether. After a couple of months during which we had met almost regularly, he stopped answering my calls. I lost track of him eventually, just as the Bellevue Centre did; anything might have occurred, from his having returned to Senegal, to having been repatriated or having lost his accommodation. My account of Samba's suffering is thus limited to the short time we spent together.

I met Samba at his place and at a café next to Foyer93, not far from his workshop. At the beginning, Samba would not talk of his illness, apart from admitting that the car accident had dramatically changed his life. It was when we started seeing each other more frequently that he elaborated on his suffering. It became clear that his affliction had to do with his dissatisfying way of life in Paris, the lack of family and the impossibility of feeling an attachment to the people in France as he had back home, from which ensued anxiety and disorientation. His regret at not having a wife was also related to the stigma that his status as a single man entails in his Muslim and conservative milieu, where sexual satisfaction is only sanctioned within marriage.

Dial's analysis of marriage in Senegal shows how it marks the entry in society and independence from the family of birth, which lose their control over the couple. ${ }^{35}$ For many, marrying and then divorcing has become a strategy of social advance, as much as a way of affirming one's perceived role and sexuality, especially in the urban context of Dakar. At the Dakar Fann Hospital, Professor Babakar Diop used a Lacanian reading of the family dynamics in his clinical work, where different metaphors and symbols represented the cultural traits of the traditional Wolof society. The husband, for example, representing law and authority, geno baye, is also the one who can pass on the baraka to his children, while the 'mother's good work' may bring good fortune to them. ${ }^{36}$ For Samba, not having a wife was tantamount to being emasculated, not having a leadership role (over the wife and in the family), and eventually, not being able to pass on his baraka.

Transtext(e)s Transcultures 跨文本跨文化, 12 | 2017 
In a way, Samba compensated for the latter by teaching children the Koran and Cheick Amadou Bamba's qasidas, or religious poems. He said that this was very important, so that the new generation of Muslims in France would not lose contact with their Muslim and Mouride tradition.

Samba received children in his house, where people he knew entrusted them to him with his teaching. He gave accounts of his lessons with passion and serenity, which he did not show when speaking of other moments of his day, which all came across as a source of anxiety. Not only did teaching the children take place at his place, thus in a familiar environment to him, but also, as a teacher, his skills were employed in one of the most heartfelt values within the Mouride community: the education of the new generation in line with Cheick Amadou Bamba's lesson of tarbiyya, or esoteric science. Samba taught them the rudiments of Arabic writing and reading, a few of Cheick Amadou Bamba's qasidas and the most important prayers of the Koran, such as the Al-Fatiha, the opening, ritual prayer of the Koran deemed capable of warding off evil influences.

He talked extensively of the importance of doing things for others and of doing good as a way of gaining baraka. In Islam, it is conceived of as the sacred gift Allah concedes to His 'friends', the holy men, wali, but also as a quid, which people can obtain by praying sincerely, or by being at the service of the community and, generally, by doing good deeds, such as carrying out the five pillars of Islam, visiting the saint's tomb, zyad, by bringing back bottled holy sand from Touba (the sacred town of the Mourides), and by obeying one's marabout, the Sufi spiritual leader. In sum, both spiritual and material practices may enable the faithful to receive such a blessing.

Samba hinted at the idea that his illness was ultimately part of God's design. He thought of it as a condemnation: God had mysteriously decided that he should be ill, that this should be his fate. In his words:

Everything comes from Allah, so if He's s not happy with you, well, you won't have a very good life. Or it might happen that if you suffer in this world, you'll be happier in the beyond. Certainly, it's not money that counts, it's doing things in moderation, not thinking badly of other people and hoping that, little by little, by every good action you do you'll be rewarded (...). Some people though, no matter what they do, won't be happy in this life.

21 His 'fate' did not obviate his guilt for all the things that he was unable to achieve and that are endorsed, or their lack thereof stigmatised, in his milieu. Samba made sense of his situation with social arguments (not being married and not being able to go home), medical ones (his reduced mental faculties and anxiety) and symbolic ones (his condition was part of a divine project), from which he drew a kind of strength, perseverance and patience. Samba is indeed a paradigmatic case of Kleinman's concepts of illness, sickness and disease used in clinical practice at the Bellevue Centre. Yet, he is also one of the very few migrant patients from West Africa attending the Centre, if not the only one loosely related to Foyer93.

\section{Working with the Jinns}

\section{An Islamic Cosmogony of Wellbeing}

Pitt-Rivers notes the remarkable absence of anthropological literature on the subject of grace, an exception being made for the works of Mauss and Lévi-Strauss for whom, 
respectively, the concepts of gift and exchange entail that of gratuitous reciprocity, 'the cement which holds any society together' ${ }^{37}$ Divine grace is solicited by sacrifices, since 'the offering invites a return-gift of grace, the friendship of God'.$^{38}$ Unlike the relatively scarce literature on the subject of grace, that of baraka enjoys broad attention in Islamic studies.

Werbner talks of a 'symbolic complex of blessing', in which barkat is only one term among several that specifically refers to a particular form of saintly power, which is not only for healing and exorcism. ${ }^{39}$ In this sense, 'it is a generic Islamic term for divine blessing. Barkat imbues objects, such as the salt given by the Sufi saint, with the power of procreation, life, fertility and so on. ${ }^{40}$ 'Barkat is magic and contagious. This means that the Sufi saint is charged physically with it, which explains why he is constantly mobbed by devout followers, endangering his life in their attempts to touch him'. ${ }^{41}$ Barkat can thus be transmitted metonymically as well as metaphorically to things, 'crystallising embodied connections between a sacred centre and its extended peripheries'. ${ }^{42}$

Within the Islamic tradition, the jinn humanlike spirits, live a parallel life to that of humans. Some troublesome jinn are said to attack people and interfere with their lives, creating troubles of the mind and misfortune. They are mentioned in the Koran, Sura 72, and variously in the Hadith of the Prophet, as having been created from the 'smokeless flames of fire', from where also shaytan, Satan, is thought to originate..$^{43}$ The jinn can see the humans, who in turn, can 'see' and 'own' them. Interestingly, from the Arabic root of the noun jinn derives the word maynuun mad', and' مجنون also reflected in the Soninké distinction between waxanté, madness, and jinebena, that is, possession of the jinn. ${ }^{44}$

Among the Soninkés, while withdrawal indicates the presence of a problem, generally associated with depressive states, possibly linked to professional deception, confrontation, disputes, and bizarre look and behaviour testify to one's madness, while courage and dynamism are characteristics of the Soninké 'sane' identity. ${ }^{45}$ Mental illness in this context thus manifests itself as a kind of extravagance in comparison to the Senegalese and Bambara groups, where descriptions revolve around ideas of a nonintegrated self - fato in Bambara. Jinebena, on the other hand, is described as affliction brought about by mystical agents. In my respondents' view, both illness and affliction, their causality and effects are human destiny; non-Muslim and Muslims undergo the same suffering, physical and mental, but act upon it differently. Ultimately, illness and health unfold in mediation, or through a process of negotiation with the spiritual realm, which requires the intervention of a marabout-healer and implies the essentially nonpsychotic nature of the possessed..$^{46}$ Hence, the puzzlement of the clinician in discerning the interaction between cultural statements of alleged attacks of the jinn, as reported by Muslim patients, and episodes of illness that fall within conventional medicine. Indeed, some patients only recover after resorting to traditional healing. ${ }^{47}$

According to my respondents, the ontological complexity of baraka adds to the confusion existing in Europe regarding who is a marabout, a healer or one who practises magic or witchcraft, all equally employed as synonyms for charlatans. The difference between marabout and marabout-healer is one which separates the domain of baraka, the mystical power channelled by God, from that of lasrar, magical knowledge, which could also be used to harm people. Ousmane, a young resident of Foyer93, aged twenty-four, said to me:

Because we believe in Islam, we think that the world doesn't stop here. All is connected to the same source, which is eventually spiritual. What you see and what 
you don't see is there. We don't know why, God's plan for us all is a mystery. Affliction, supersedes illness and takes shape in many ways. It can be an attack of the jinn, as much as misfortune. The marabout only prays to God yet, exceptionally, he can take excerpts from the Koran, write them on paper and give it to you, so that you'll wear it. Wearing the amulet is important because it will be with you at all times and thus protect you. Nevertheless, that is the marabout-healer's job. Healers normally belong to your circle, people you trust that have gone through similar problems as you have here in Paris, so you feel confident enough to open yourself and tell them your deepest problems.

Notwithstanding the distinction between tradition and Islam, which makes ordinary believers frown upon those resorting to healers, all of my respondents frequent healers to solve their day-to-day concerns. When they worry about their legal status (many have temporary visas or no documents at all), their children's upbringing and marriage, their family back home or their lives in France, they will easily turn to healers. My respondents think that in the face of illness both medicine and traditional healing are valid as the Koran states that Muslims are compelled to heal themselves by any possible means. They define themselves as the generation of change, between the country where they have chosen to live and that of origin, receptive to both worlds especially with regards to their wellbeing. They resort to western medicine as much as to their marabouts and healers, finding the former useful to treat physical ailments, while the latter better placed to deal with their concerns. For instance, both marabouts and healers deal, at different levels, with troubles of the mind, which are conceived to entail the realm of the spirits that has somehow been disrupted, and they are part and parcel of their world, first and foremost as Muslims and not least, as migrants.

\section{Ritual Healing}

During my fieldwork in Paris, I met Drame, a healer to whom I was introduced by community members at Foyer93. He held his divination sessions at his house in Barbès, an up-and-coming district in the eighteenth arrondissement of Paris, where recently opened art shops, bookshops, little ethnic restaurants and night clubs attract both the locals, mainly of Western and Northern African origin, and the bohemian glitterati of Paris, who enjoy the atmosphere of the rich cultural mix in this part of town.

Drame underlined that his clientele belonged to his own circle of people, a proof of sorts of his talent and renown which in fact, should normally not need advertising. As he put it, those who stand at metro stations publicising themselves as miracle workers certainly are not and they spoil the image of the 'real ones' vis-à-vis the French. If someone is a good healer, people in the community know, as the information is spontaneously passed on and circulated. Drame is also said to confront liguééy, sorcery. People consult him when they think that somebody, or the jinn, either in Senegal or in France, is trying to harm them or when they wish to achieve or change something in their lives. Problems may vary from an attack of the jinn, alcoholism, infidelity, sexual impotence to 'wrong' marital matches. The last time I visited him, a woman was there to ask Drame to 'break' her son's relationship with a girl. Caste affiliations are partially still present and add to the social stratification of the Soninké society; although with migration caste has become less meaningful due to social mobility and similarity of status within the migrant working class, marrying into a lower caste is disapproved of. The woman mentioned was from a 
maraboutic family and wished her son to marry within his own milieu, yet as her son's girlfriend belonged to a family of griot descent, she found it dishonourable. ${ }^{48}$

Overall, the ritual implies the use of the hatim, a grid associating a numerological system to the letters written in Arabic corresponding to the name of the person (or other personal detail) involved. The resulting number provides a formula that is then used for protection. One of these, called the formula of Souleymane, is deemed useful to heal all kinds of illnesses. Translated from the Arabic, it reads: 'a marabout is working to take you', meaning that the marabout is casting away the jinn. Other grids apply different letters, which therefore result in different numerical combinations and formulas:

\begin{tabular}{|c|c|c|c|}
\hline$d \stackrel{2}{=} 4$ & $\stackrel{?}{\mathrm{e}}=3$ & $\begin{array}{l}\dot{\varphi} \\
b=2\end{array}$ & $\begin{array}{c}1 \\
a=1\end{array}$ \\
\hline $\mathrm{h}=8$ & $\underset{z=7}{j}$ & $\stackrel{9}{=} 6$ & $\begin{array}{c}\infty \\
\mathrm{He}=5\end{array}$ \\
\hline $\begin{array}{c}J \\
L=30\end{array}$ & $\begin{array}{c}b \\
\operatorname{ta}=20\end{array}$ & $\begin{array}{c}\checkmark \\
\mathrm{i}=10\end{array}$ & $\stackrel{2}{\text { Tua }}=9$ \\
\hline$\stackrel{\varepsilon}{\varepsilon}=70$ & $\begin{array}{c}ص \\
s=60\end{array}$ & $\begin{array}{c}\bullet \\
\mathrm{n}=50\end{array}$ & $\mathrm{~m} \stackrel{?}{=} 40$ \\
\hline$\stackrel{\jmath}{r}=200$ & $\begin{array}{c}\overrightarrow{0} \\
q=100\end{array}$ & $\begin{array}{c}\dot{ض} \\
\text { da }=90\end{array}$ & $\begin{array}{c}\dot{1} \\
\mathrm{f}=80\end{array}$ \\
\hline $\begin{array}{c}\dot{\tau} \\
\mathrm{Kh}\end{array}$ & $\begin{array}{c}\stackrel{\Xi}{*} \\
\text { tha }=500\end{array}$ & $\begin{array}{c}ت \\
\mathrm{ta}=400\end{array}$ & $\begin{array}{c}\omega \\
s=300\end{array}$ \\
\hline $\begin{array}{c}\text { ش } \\
\mathrm{Ch}=1000\end{array}$ & $\begin{array}{c}\dot{\varepsilon} \\
\text { Rahine }=900\end{array}$ & $\begin{array}{c}\dot{\dot{x}} \\
\mathrm{zha}\end{array}$ & $\begin{array}{c}\dot{j} \\
\mathrm{dh}=700\end{array}$ \\
\hline
\end{tabular}

Drame summons rauhan and khudan, a kind of jinn, to guide him during divination. According to him, not all practitioners have the power to deal with these spirits, since they only associate with men of the highest spirituality, virtue and knowledge of the Koran. The intervention of the guiding spirit may in fact fail to happen if the practitioner has misbehaved or failed to accomplish his prayers. In this case, he should praise the spirits and gain their intervention by asking forgiveness. The Surat Al-Jinna - the seventy-second in the Koran and the twenty-eighth of the Revelation - is useful for this purpose ${ }^{49}$ The pantheon of the jinn is therefore crucial, since they are the practitioner's allies, without whom he could not operate. Reparation thus entails mediation in different realms, where what is at stake is not only the resolution of the problem, but also a wider equilibrium which needs rebalancing. The success of the practitioner's intervention lies in his moral standing, so that good, as opposed to evil, is not only a Muslim principle of behaviour, but embodied spirituality attained through practice, a source of healing power which is put to use for the good of the community. During divination, all the agents involved undergo a testing.

Resorting to marabouts can also be propitiatory: because they are conceived to be dealing with the spiritual realm, they bring baraka, understood in the widest sense possible. Baraka can be the marabout's advice, his fabrication of protective objects, his power to deal with, see or push the jinn away from the victim. My respondents think that the validity of the marabout's intercession is limited in time and contextual to the problem and situation. Amulets and prayers have to be reproduced and performed on any new 
occasion, as life goes on, in order to keep troubles at bay or to escape them when these arise.

The residents of Foyer93 endorse marabout-healers for their skills, but most often because of what they represent: their common tradition, language, identity and needs. Marabout-healers belong to same milieu as their clients' and experience in the same way the difficulties of settling into in the big city. For many, obtaining a residence permit or avoiding a police-check can be reason enough to visit one of them. Whether or not the marabout-healers be trustworthy or considered to be less powerful than those left in the home country my respondents' belief system remains unquestioned and its practice unperturbed. ${ }^{50}$ Marabouts and marabout-healers guarantee the marginal, yet vital space of hope that things can be manipulated, turned in their favour, and that the spiritual realm, as opposed to the law, can still satisfy their demands as human beings.

Notwithstanding the endeavours of French transcultural psychiatry to alleviate migrant's afflictions and to bridge the gap that exists between the wider French society and firstgeneration migrants, it still cannot extend its medical provision to people like the residents of Foyer93. Such a possibility is already impeded by their feeling increasingly and more consciously that what France offers is not designed for them, they who are socially marginal and attached to their own values. They sense that French healthcare, premised on a secular and disenchanted standpoint, is ultimately detached from their most immediate needs and spirituality. This points rather to the need for a form of mediation, which would see them and their interlocutors (healers, associations and religious leaders) at the centre of the process, not unlike the psychiatrist Collomb's pioneering community-based project that proved to be successful. Marabouts and marabouts-healers still give them the guarantee to be listened to, understood and fortified in their spiritual and social quest. Hence, among West African migrants, the former's role flourishes in the wider setting of health and the realm of divination and anti-sorcery, which reinforce the belief in the baraka as their unique spiritual way of understanding the world and of dealing with it.

\section{NOTES}

1. The French Foyers des Travailleurs Migrants are housing centres for exclusively male migrants.

2. All the names of people and professional bodies are pseudonyms used to protect my respondents' anonymity.

3. https://www.insee.fr/fr/statistiques/2020940?geo=DEP-93\&sommaire=2106113\#IMG1A_ENS

4. Henceforth, it will be referred to as Foyer93.

5. René Collignon, "Émergence de la psychiatrie transculturelle au lendemain de la seconde guerre mondiale (Références Africaines)" in M.R Moro., Q. De la Noë and Y. Mouchnick (eds.), Manuelle de Psychiatrie Transculturelle: Travaille Clinique, Travaille Sociale, Grenoble, La Pensée Sauvage, 2004, p. 79-107.

6. Collignon, p. 80.

7. Collignon, p. 82. 
8. See Franz Fanon F., Black Skins White Masks, Harmondsworth, Penguin, [French ed.1952] 1967, and Franz Fanon, The Wretched of the Earth, London, Macgibbon \& Kee, [French ed. 1961] 1963.

9. Collignon, p. 83.

10. Roland Littlewood, "Science, shamanism and hermeneutics. Recent writing on psychoanalysis", Anthropology Today, v. 5, n. 1, 1989, p. 5.

11. Andras Zempleni, "La dimension thérapeutique du culte du rab: Ndöp, Tuuru et Samp. Rites de possession chez les Lebou et les Wolof", Psychopathologie africaine, v. 2, n. 3, 1966, p. 295-439.

Marie-Cécile Ortigues and Edmond Ortigues, EEdipe Africain, Paris, L'Harmattan, 1984.

12. Carolyn Sargent, Stéphanie Larchanché, "Sur les pas de l'anthropologie médicale clinique en France : la maturation d'un approche sur la place de la culture dans les soins de santé mentale", Transfaire et Culture, 1, 2009, p. 101.

13. See George Devereux, Ethnopsychoanalysis: Psychoanalysis and Anthropology as Complementary Frames of Reference, Berkeley, University of California Press, 1978. See also George Devereux, Basic Problems of Ethnopsychiatry, Chicago, University of Chicago Press, 1980.

14. Sargent and Larchanché, "Sur les pas de l'anthropologie médicale clinique", p. 102.

15. Didier Fassin, Pouvoir et Maladie en Afrique: Anthropologie Sociale dans la Banlieue de Dakar, Paris, PUF, 1992.

16. Didier Fassin, "L'ethnopsychiatrie et ses réseaux : L'influence qui grandit", Genèses, v. 35, n. 35, 1999, p. 146-171.

Tobie Nathan, L'Influence qui Guérit, Paris, Odile Jacob, 1994.

17. Fassin, "L'ethnopsychiatrie et ses réseaux", p. 151 (my translation).

18. Roland Littlewood and Maurice Lipsedge, Aliens and Alienists: Ethnic Minorities and Psychiatry, London, Routledge, [1982] third edition, 1997.

19. Fassin, "L'ethnopsychiatrie et ses réseaux", p. 154 (my translation and emphasis).

20. Didier Fassin, "Le droit d'avoir des droits", Hommes et Migrations. Santé et Droits des Étrangers : Réalités et Enjeux, n. 1282, 2009, pp. 20-23.

21. Littlewood and Lipsedge, Aliens.

22. Marie-Rose Moro, Quitterie de la Noë and Yoram Mouchenik, Manuel de Psychiatrie Transculturelle, Grenoble, La Pensée Sauvage, 2006.

23. Marie-Rose Moro, Enfants d'Ici Venus d'Ailleurs: Naître et Grandir en France, Paris, La Découverte, 2002.

24. Michel Fievet, Le Livre Blanc des Travailleurs Immigrés des Foyers: Du Non-Droit au Droit, Paris, L'Harmattan, 1999.

25. The banlieue, which literally means lieu banni, banned place, is first of all a peripheral territory, where different socio-economic realities co-exist.

26. Carolyn Sargent, "Reproductive strategies in Islamic discourse", Medical Anthropology Quarterly, 20, 1, 2006, p. 31.

27. David Lessault and Cris Beauchemin, "Les migrations d'Afrique subsaharienne en Europe: un essor encore limité”, Population \& Sociétés, n. 452, 2009, p. 224.

28. Mahamet Timera, Les Soninké en France: D'une Histoire à L'autre, Paris, Karthala, 1996.

29. Leon Eisenberg, "Nature, niche and nurture: the role of social experience in transforming genotype into phenotype”, Academic Psychiatry, 22, 1998; p. 213-222.

See Arthur Kleinman, Patients and Healers in the Context of Culture: An Exploration of the Borderland between Anthropology, Medicine, and Psychiatry, Berkeley, University of California Press, 1980.

See also Arthur Kleinman, The Illness Narratives: Suffering, Healing, and the Human Condition, New York, Basic Books, 1988.

30. Simon Dein, "Against belief: The usefulness of explanatory model research in medical anthropology", Social Theory and Health, 1, 2, 2003, p. 149-162.

31. Rachid Bennegadi, Marie-Jo Bourdin and Christophe Paris, "Santé mentale des migrantes et des réfugiés : le cadre de l'anthropologie médicale clinique", Transfaire \& Culture, 1, 2009, p. 15. 
32. Bennegadi, Bourdin and Paris, p. 11.

33. The Senegalese Cheick Amadou Bamba M'Backé (1855-1927), is the founder of the Mouridyya (from the Arabic mouridoullah, literally 'aspirant to God'), a Sufi branch of Islam. The Mouride talibé are the faithful of the order.

34. It is a card which entitles only those who have worked in France for at least three months and who can provide an address to benefit from healthcare schemes.

35. Fatou Binetou Dial, Mariage et Divorce à Dakar: Itinéraires Féminins, Paris, Karthala, 2008.

36. Baraka, from the Arabic بركة barkat, is the divine gift that saintly and virtuous men are thought to possess through their proximity to God. See also next paragraph.

F.B. Dial, review of René Collignon, Mariage et Divorce à Dakar: Itinéraires Féminins, Karthala, Paris, 2008, Psychopathologie Africaine, v. 24, n. 3, 2008, p. 415-421.

37. Julian Pitt-Rivers, 'Postscript: the place of grace in anthropology' in J.G Peristiany. \& J. Pitt-Rivers J. (eds.), Honour and Grace in Anthropology, Cambridge, University Press, 1992, p. 218.

38. Pitt-Rivers, p. 223.

39. Pnina Werbner, Pilgrims of Love: The Anthropology of a Global Sufi Cult, London, C. Hurst., 2003, p. 250.

40. Werbner, Pilgrims, p. 251.

41. Werbner, Pilgrims, p. 252.

42. Pnina Werbner and Helen Basu, "The embodiment of charisma" in P. Werbner, H. Basu (eds.), Embodying Charisma: Modernity, Locality and the Performance of Emotion in Sufi Cults, London, Routledge, 1998, p. 13.

43. Najat Khalifa and Tim Hardie, 'Possession and jinn', Journal of the Royal Society of Medicine, v. 98, n. 8, 2005, p. 351.

44. The Soninkés are a subdominant ethnic group, stretching between Senegal and Mali along the Senegal River Valley. They are part of the Mande greater family group, comprising the Bambara and the Mandinka ones.

45. Ellen Corin, Gilles Bibeau, Elisabeth Uchôa, "Éléments d'une sémiologie anthropologique des troubles psychiques chez les Bambara, Soninké et Bwa du Mali", Anthropologie et Sociétés, v. 17, n. 1-2, 1993, p. 125-156.

46. See the following authors: Roberto Beneduce, Trance e Possessione in Africa: Corpi, Mimesi, Storia, Torino, Bollati Boringhieri, 2002. Michael Lambek, Human Spirits: A Cultural Account of Trance in Mayotte, Cambridge, University Press, 1981. Clemens Zobel, "Les génies du Kòma: identités locales, logiques religieuses et enjeux socio-politiques dans les monts Manding du Mali”, Cahiers d'Études Africaines (Cahier 144, Mélanges maliens), v. 36, n. 144, 1996, p. 625-658.

47. Khalifa and Hardie, 'Possession and jinn', p. 351-353.

48. Maraboutic families stand for the traditional religious élite and hold great prestige.

The griots, who used to be the bards chanting the epic of the Soundiata Empire, are still the repositories of the Soninké oral tradition.

49. The Suras are ordered in the Koran by length, and therefore, they do not follow the chronological order in which they appeared historically. This explains why, Muslims refer in the first case to the standard order, while in the latter to the 'Suras of the Revelation'. Thus, they produce a different way of counting.

50. Murray Last, "The importance of knowing about not knowing", In: R. Littlewood (ed.), On Knowing and not Knowing in the Anthropology of Medicine, California, Left Coast Press, 2007, p. 1-17. 


\section{ABSTRACTS}

This paper addresses several issues of significance in the field of migration and health, transcultural psychiatry and the politics of healthcare, in order to reflect on the integration of the Muslim West African population in France. My analysis is based on ethnographic fieldwork that I carried out in Paris, in a clinic that targets migrant patients with psycho-social dilemmas and in a foyer among Soninké migrants from the region of Kayes, Mali. The reader is introduced to two case studies that shed light on the detachment existing between migrants and the mainstream healthcare offered to them. Arguably the divide interlaces with the particular secular, positivistic emphasis that moulds, epistemologically and culturally, French civil society as a whole, as opposed to other traditional, religious worldviews that understand healing as a symbolic and spiritual experience achieved through ritual.

\section{AUTHOR}

\section{DAFNE ACCORONI}

Dafne Accoroni is an anthropologist whose expertise in the field of Migration Studies is based on years of qualitative and analytic research carried out first as a $\mathrm{PhD}$ researcher at University College London University and secondly as a Marie Curie postdoctoral researcher at Jean Moulin University, Lyon. At UCL, Accoroni worked on integration and health (i.e. access to health and housing; community support, copying strategies, secularism and so on) among Western African minority groups in France. Her Lyon-based fieldwork revealed an important Moroccan component, which led her to carry out explorative research in Marrakech, Morocco, and to extend her spectrum of interest to North Africa. Accoroni is an Associate member of the Université Lyon3, to which she contributes by working on the themes of cultural and linguistic diversity and representations of health with regard to Francophone African migrants. 